UDK 930.1:94(477)(=16)

DOI: 10.24919/2519-058x.9.150357

Kostiantyn IVANGORODSKY,

orcid.org/0000-0002-4052-5253

PhD (History), Associate Professor of Ukraine's History Department Bohdan Khmelnytsky National University of Cherkasy (Ukraine, Cherkasy) iwakos@ukr.net

\title{
METHODOLOGICAL ASPECTS OF THE RECONSTRUCTION OF THE EAST-SLAVS ETHNIC HISTORY IN THE MODERN UKRAINIAN HISTORIOGRAPHY
}

\begin{abstract}
Modern Ukrainian historians, during the reconstruction of the East Slavs' ethnic history before the Mongol era, rarely adhere to clearly formulated methodological guidelines and theoretical postulates that allow such studying. Therefore, for contemporary Ukrainian historiography of this problem are inherent outdated rudiments of «Soviet positivism», misunderstanding and reluctance to apply modern western approaches, conscious self-isolation within the national narrative. The main idea of the article is to show that in modern Ukrainian historiography there are no satisfactory methodological principles for the scientific reconstruction of the East Slavs' ethnic history, and most Ukrainian researchers are still confused by the conditions of methodological pluralism. The purpose of the study is to analyze the methodological aspects of the reconstruction of the East Slavs ethnic history in contemporary Ukrainian historiography. This scientific topic has not been analyzed in historiography till now, so the problem, we have raised, has acquired such a value for the first time. The methodology of the research is determined by the critical analysis and is based on the principles of historicism, systematic, scientific, ethnological verification, objectivity, ethnosocial constructivism, moderate relativism, methodological pluralism. In order to solve this problem, were used such historiographical methods as analysis, synthesis, «second level historiography», comparative, hermeneutic, abstract, historical-genetic, typological, terminological analysis. The scientific novelty is determined by the fact that for the first time, with the method of remote monitoring and analysis (so-called method of «second level historiography») is clarified the development of methodological foundations of the newest Ukrainian scientists' researches devoted to the reconstruction of the East-Slavic communities' ethnic history in the pre-Mongol era. The comparative approach allowed us to trace the influence of methodological pluralism on modern Ukrainian historiography and to establish the significant methodological confusion and ignorance with new tendencies among historians and other humanitarians. Conclusions. The reconstruction of the East Slavic communities' ethnic history, including the Ukrainians ethnogenesis, is one of the key issues in modern Ukrainian historiography. The proposed analysis shows that in Ukrainian historical science there is no satisfactory transformation of the identified segment of cognition, and most Ukrainian humanitarians are confused in the terms of methodological pluralism. On the other hand, many leading historiographers in modern Ukraine mark the significant changes in this area during last decades, that allows us to believe in improving the situation, including the situation in ancient ethnical history researches.
\end{abstract}

Key words: methodology, historiography, ethnic history, ethnogenesis, East Slavs.

Костянтин ІВАНГОРОДСЬКИЙ, кандидат історичних наук, доцент кафедри історії України Черкаського начіонального університету імені Богдана Хмельницького (Черкаси, Украӥна) iwakos@ukr.net

\section{МЕТОДОЛОГІЧНІ АСПЕКТИ РЕКОНСТРУКЦІЇ ЕТНІЧНОЇ ІСТОРІЇ СХІДНИХ СЛОВ'ЯН У СУЧАСНІЙ УКРАЇНСЬКІЙ ІСТОРІОГРАФІЇ}

Мета дослідження - проаналізувати методологічні аспекти реконструкиії етнічної історії східних слов'ян у сучасній українській історіографії. Методологія дослідження зумовлена 
критичним аналізом і спирається на принципи історизму, системності, науковості, етнологічної верифікації, об'єктивності, етносочіального конструктивізму, поміркованого релятивізму, методологічного плюралізму. Для вирішення поставленої проблеми були залучені такі історіографічні методи, як аналіз, синтез, «історіографії другого рівня», компаративний, герменевтичний, абстрагування, історико-генетичний, типологічний, термінологічного аналізу. Наукова новизна визначена тим, що вперше засобом відстороненого спостереження та аналізу (так званий метод «історіографії другого рівня») з'ясовано розвиток методологічних основ новітніх досліджень українських учених, які присвячені реконструкиіям етнічної історії східнослов'янських спільнот домонгольської доби. Компаративний підхід дозволив простежити напрями впливу на сучасну украӥнську історіографію методологічного плюралізму та встановити істотну методологічну розгубленість і необізнаність із новими тенденціями у середовищі істориків і решти гуманітаріїв. Висновки. Реконструкиія етнічної історії спільнот східних слов'ян, у тому числі етногенез украӥнців, становлять у сучасній українській історіографії одну з ключових проблем. Пропонований аналіз свідчить, щзо поки в історичній науці Украйни немає задовільних трансформачій означеного сегменту пізнання, а більшість украӥнських гуманітаріїв перебувають у стані розгубленості в умовах методологічного плюралізму. 3 іншого боку, чимало провідних історіографів сучасної України констатують істотні зрушення в иій сфері останніх десятиліть, щзо дозволяє висловити позитивні сподівання на покращення ситуації зокрема й стосовно досліджень етнічної історії давнього минулого.

Ключові слова: методологія, історіографія, етнічна історія, етногенез, східні слов'яни.

Statement of the problem. In our opinion, the Eastern Slavs' ethnic history study requires historians, first of all, to clearly formulate methodological guidelines and theoretical postulates that facilitate such a research. Unfortunately, modern Ukrainian experts in this area seldomly adhere to this position. In general, in contemporary Ukrainian historiography, this problem is characterized by outdated rudiments of «Soviet positivism», confusion with methodological pluralism, misunderstanding and reluctance to apply modern Western approaches, conscious self-isolation within the national narrative. On the other hand, we cannot but mention the significant breakthroughs in the methodological research of the past, which are demonstrated by the most recent works of Ukrainian historians, demonstrating the openness of Ukrainian historiography to changes in this aspect.

Research analysis. The claimed themes do not have a special analysis in the humanitarian space yet, and, therefore, the problem that we tackled for the first time acquires a considerable significance. In the general context, the specificity and certain aspects of the methodological development of modern Ukrainian historiography are presented in the works of Ya. Hrycak, L. Zashkilniak, G. Kasianov, I. Kolesnyk, O. Tolochko, N. Iakovenko and others.

The purpose of the article. Applying the principle of «second level historiography» proposed by G. Kasianov (analogous to the concept of «second level observer»), when the object of observation is not facts, but the process of observing these facts (Kasianov, 2010: 237), we will try to trace the reflection of Ukrainian scholars on the methodological position of Ukrainian historiography in relation to the ethnic history of the Eastern Slavs.

Statement of the main material. Despite the pessimism of some Ukrainian scientists regarding the lack of methodological innovations in the contemporary humanitarian discourse of Ukraine, the changes themselves in this direction are eloquently evidenced by a much more confident (as compared with its neighbours) progress towards integration into the world's science. Already in the 1990's such a situation was evidenced by the publication of two propaedeutic courses on the methodology of the history by the famous Lviv historian L. Zashkilniak (Zashkilniak, 1996, Zashkilniak, 1999), which, according to the observation by I. Kolesnyk, by the very fact of articulation of the problems raised in them: «Destroyed 
the notion of the absence of methodology in Ukrainian historical science» (Kolesnyk, 2001: 82). It is significant, that the main methodological transformations within the limits of historical science take place first of all in the segment of historiographical analysis proposed by Ukrainian historians.

According to Ya. Kalakura, contemporary Ukrainian historians face the problems of uncertainty and conflict of methodologies, which is manifested in their «floundering» between the remnants of Soviet normalization and new approaches to historical writing (Kalakura, 2016: 76). That also became the reason of the one-sided methodological interpretation of ethnic history problems of the Eastern Slavs community, which, in addition to the politicized deformations, has acquired at the newest stage a noticeable «nationalization». Turns out, that in our case, the ideologists of the previous narrative turned out to be the most successful practitioners of national history. This is also connected with the prevalence in modern Ukrainian historiography of «naive positivism» in relation to ethnogenetic research, when even at the scientific level it is possible to reconstruct the ethnic history of the Eastern Slavs' communities, for example, exclusively in archaeological materials.

It is significant that among the representatives of such a vision there is virtually no discussion of the methodological and theoretical foundations in their research practices, and their works do not evidence the benefits of this position. As a rule, such intentions are declared, but not specified. The characteristic opinion of V. and Ya. Baran about this issue is declared in the following statement: «Our work on the new methodological basis reveals the processes of ethno-historical development of the Slavs on the territory of Eastern Europe and Ukraine in particular» (Baran, 2005: 7). However, the concept of the «new methodological basis» is not explained by archaeologists, but instead (without justification and explanation), they provide a number of rather dubious concepts. For example, they declare the Slavs to be «an ethno-social unit», and the Kyiv princes, appear to have created an «imperial state». It is worth noting the lack of Ukrainian researchers' knowledge of the «new methodologies», and therefore it is rather delusive to consider that their solid state-based scientific works are based on the «prEmordialism approach» (italics are ours - author) (Videiko, 2015: 341).

The situation did not improve much in the East Slavic ethno-history domain after an involuntary redirection of specialists to the so-called «civilizational approach». Nowadays, almost complete absence of theoretical and methodological developments of civilization theory has transformed it essentially from the methodology into «civilization terminology», and such an abstraction as «civilization» is used more as a tribute to the intellectual trend without any scientific substantiation. I. Kutsyi quite reasonably states that the concept of «civilization» is as meaningful, as the scientific interpretations of the essence of a civilizational approach are vague and contradictory (Kutsyi, 2016: 13). At first, civilization discourse was perceived as the main means for dismantling of the formation aberration, which dominated in the Soviet history, but it soon revealed that such an approach was not an epistemological panacea.

Some of the Ukrainian scholars, mechanistically and extremely unsuccessfully, tried to replace the Marxist rhetoric of their concepts with «civilizational imperatives», avoiding any methodological explanations in this regard. For example, M. Kotliar, claiming in the title of one of the monographs to shed the light on «the origins of the East Slavic civilization», did not even outline the boundaries of this lexical occasionalism, besides, he mentioned it only once in the book, namely in the afterword (Kotliar, 1995: 278). In the same way, this artificially fictitious term was used by archaeologist O. Motsia, doubtlessly proclaiming the «Kyiv period of the East Slavic medieval civilization history» (Mot- 
sia, 2007: 4). Even more problematic is the attributing of the epithet «civilizational» to individual archaeological cultures, hypothetically related to the ethnogenesis of the Eastern Slavic cultures, for example Chernyakhivska. Instead, in solidarity with S. Plokhy, it should be noted that discussions about any «East Slavic civilization», fuelled simultaneously by the Russian, Belarusian and some Ukrainian politicians, are senseless at the background of the current nationalization of post-Soviet societies (Plokhy, 2006: 361). At the same time, the process of «nationalization» of history in Ukrainian historiography is not only the search and crystallization of its own identity, but also the identification of those who should be excluded from «their own» community. As a result, ethnic and cultural indicators have become natural means of «alienating» both for professional historians and for politicians and ideologues. Formation of the image of the ethnic «other» has become an integral part of both cultural and political mobilization, the implementation of the memory policy in the newly-established states. In addition, a significant part of the professional historical community has become, in this regard, not only the executor of the corresponding «state order», but also a significant factor in influencing the formation of this order. Therefore, the ethnic history of the Eastern Slavs is still more an ideological construction, reverted into the formula of scientific knowledge, than the latter.

When representing ethno-historical issues, any historian should be as careful as possible, since the past is an insidious advisor for the vision of the modern image. At the same time, it should be noted that, being an instrument of collective self-identification, history in essence will always be its only means, which is based exclusively on the opposition of «self» and «other» (Zashkilniak, 2016b: 16). Hence, the methodological situation in the countries of the former USSR (precisely within nationalized history) is similar, although they overcome it differently. From the 1990's, within the historical science of Ukraine, two «camps» of scholars have been identified in the study of the ethnic history of the Eastern Slavs, which, according to G. Kasianov, could be called «primordialists» and «modernists» according to the methodological priorities. The first party is still the dominant trend in Ukrainian historiography, which involves the search, first of all, of the Ukrainian ethnic roots in antiquity. In this perspective, the «biological» (L. Zalizniak), the «cultural» (A. Ponomariov) and the «politico-genetic» (Y. Dashkevich, Y. Isaevich) variants are selected (Kasianov, 1999: 264-270).

It is noteworthy that the «camp» of the so-called «modernists», in general (!), does not address the topic of ethnogenesis of any communities that lived on the Ukrainian lands until the seventeenth and eighteenth centuries, which, according to our conviction, deprives ourselves from important reasons for the true knowledge of Ukrainian identity formation in the «era of nationalism». Separate attempts to study the ethnic history of Eastern Slavic communities from «non-traditional» methodological approached cannot be considered too convincing. In general, we can note only two attempts like these in the entire period of the development of independent Ukrainian historiography: the proposal of O. Tolochko to analyse the «Old Rus nationality» in the format of the imagined community (Tolochko, 2002: 116) and S. Plokhy's work on the formation of premodern identities in Ukraine, Belarus and Russia, on the basis of the «review of the tradition established in historiography to consider the East Slavic peoples as primordial formations» (Plokhy, 2015: IX-X). The authorial innovations of these historians are not providing the resolution of the key problem: who, by ethnicity / identity, were «Eastern Slavs» in pre-state times?

Transformations in the methodological sphere of modern Ukrainian historiography are essentially a process of gradual accumulation and stratification of new and old trends. On the 
other hand, without going through the strict and demanding school of modernism, «school of source and method», one should not approach the elegant lace metaphor, allusions and illusions of postmodernism (Pidhaietskyi, 2000: 315). In general, it must be admitted that most Ukrainian contemporary historians were initially very suspicious of the methodological situation posed by postmodernism. However, over time, it became evident that for humanities, in general, it became a good stimulus, and therefore professionals began to turn to the innovations that postmodernism offered more and more. The most evident evolution of postmodernist epistemological practices within contemporary Ukrainian historiography, with all the «inappropriateness» and «benefits» of this process, has recently been analysed by L. Zashkilniak, who rightly emphasized that, regardless of the attitude to the postmodern situation, it is impossible to ignore its influence on historical cognition (Zashkilniak, 2016a: 105-109).

One of the most notable figures in this area of the latest Ukrainian historiography is N. Iakovenko. At the turn of the millennium, the Kyiv scientist also drew attention to the level of methodological equipment of studios in medieval history of Ukraine, stating that this branch is still largely marked by archaic practices. First of all, it is a question of «the conceptual equipment problem», when the romantic-positivist thinking is embedded in such basic categories as «ethnos», «nation», «state», etc. In addition, she provided the reasons for such a situation, like unsatisfactory professional training of Ukrainian historians and as a consequence - their failure to «penetrate» into the matter of the pre-modern epochs (Iakovenko, 2000: 61, 68). Therefore, most historians in the field of ethno-historical reconstructions still hold on the essence of the «canon» of the late nineteenth century, often adding to it the Soviet templates of historical thinking and decorating these anachronisms with foreign vocabulary (Iakovenko, 2005: 59). This can be explained by the general domination of teleological schemes in the national narrative, based on a rather chimerical Marxist teleology method, for example, presence of such a Soviet invention as «Old Rus nationality» in the historiography.

The methodological basis of such «state» (post-Soviet) direction of contemporary Ukrainian historiography, in comparison with others, looks most eclectic, trying to combine various elements of the Soviet, national and modernist trend. This is format in which the «East Slavic narrative» is presented, which still emphasizes on the "priority of unity» as the main postulate of the former Soviet discourse (Kulyk, 2012). P. Tolochko is the most prominent representative of this trend in relation to the ethnic history of Kievan Rus, and he is convinced that «Marxist formational evolutionism» is still not undermined by anyone, and therefore «Marxist understanding of the world's historical process» needs to be defended (Tolochko, 2007: 5-8). To a certain extent, such a position may be explained by the fact that after the period of "supercriticalism» in historiography, the time has come for methodological uncertainty, which has caused nostalgia among some historians.

Soviet-Russian historical heritage destructively affected the creation of historical knowledge with the immense ideological pressure, which, according to L. Zashkilniak, can be explained primarily by the complete absence of the Ukrainian national humanitarian policy and the minimal presence of Ukrainian historiography and history in world's historical science (Zashkilniak, 2015: 21, 30). The latter is distinguished by hiding ideologically and politically oriented conventions by historian designed to reflect the interests of certain influential groups. Unfortunately, many such political speculations can be observed in the discourse regarding the ethno-historical past of the Eastern Slavic communities of the pre-modern era, including the so-called «Trypillian myth». 
Conclusions. The reconstruction of the ethnic history of the Eastern Slavic communities, including the ethnogenesis of Ukrainians, is one of the key issues in modern Ukrainian historiography. The success of its solution depends largely on the methodological basis of ethno-historical research. The proposed analysis shows that while in the historical science of Ukraine there is no satisfactory transformation of the identified segment of cognition, and majority of Ukrainian humanitarians are confused in terms of methodological pluralism. The historians' desire to explore the ethno-historical past of the Eastern Slavs «in a new way» encounters the theoretical and methodological self-isolation associated with domination in the historiography of the Soviet rudiments in the process of cognition, the domination of Russian-imperial and Soviet ethno-historiographical myths and stereotypes, lack of understanding of Western methodological principles, in particular a peculiar «epistemological fear» of so-called postmodernism. On the other hand, many leading historiographers of modern Ukraine state significant changes in this area of the last decades, which allows to make positive predictions for improvement of the situation, in particular, with regard to the research of the ethnical history in ancient past.

\section{BIBLIOGRAPHY}

Баран, 2005 - Баран В. Д., Баран Я. В. Історичні витоки українського народу. Київ, Генеза, 2005. $208 \mathrm{c}$.

Відейко, 2015 - Відейко М. Ю. Етносоціальні трансформації у Центральній та Південно-Східній Європі V - IV тис. до н. е.: дис. ... д-ра іст. наук; 07.00 .05 - етнологія / Київський національний університет ім. Т. Шевченка. Київ, 2015. 462 с.

Зашкільняк, 1996 - Зашкільняк Л. О. Вступ до методології історії. Львів, ЛОНМІО, 1996. 96 с.

Зашкільняк, 1999 - Зашкільняк Л. О. Методологія історії від давнини до сучасності. Львів, Львівський державний університет, 1999. 226 с.

Зашкільняк, 2015 - Зашкільняк Л. Радянські історичні міфи в сучасній українській історіографії: «старе вино в нових міхах» // Світло й тіні українського радянського історіописання / за ред. В. Смолія. Київ, ІІУ НАНУ, 2015. С. 17-30.

Зашкільняк, 2016 - Зашкільняк Л. Про свободу і обмеження в пізнанні минулого: українська історіографія на початку XXI століття // Харківський історіографічний збірник. Вип. 15. Харків, ХНУ, 2016. C. 14-27.

Калакура, 2016 - Калакура Я. «Синдром комунізації» істориків і його живучість у пострадянській українській історіографії // Історик і Влада: колективна монографія / ред. В. Смолій. Київ, IIУ НАНУ, 2016. C. 55-76.

Касьянов, 1999 - Касьянов Г. В. Теорії нації та націоналізму. Київ, Либідь, 1999. 352 с.

Касьянов, 2010 - Касьянов Г. В. Danse macabre: голод $1932-1933$ років у політиці, масовій свідомості та історіографії (1980-ті - початок 2000-х). Київ, Наш час, 2010. 271 с.

Колесник, 2001 - Колесник І. Методологія історії чи історія методології: метафори історіографічного дискурсу // Український гуманітарний огляд. Вип. 5. Київ, 2001. - С. 55-85.

Котляр, 1995 - Котляр М. Ф. Русь язичницька: біля витоків східнослов'янської цивілізації. Київ, Заповіт, 1995. 288 с.

Кулик, 2012 - Кулик В. Націоналістичне проти радянського: історична пам'ять у незалежній Україні (2012). URL: http://www.historians.in.ua.

Куций, 2016 - Куций І. П. Цивілізаційні ідентичності в українській історіографії кінця XVIII - початку XX ст.: між Слов'янщиною та Європою. Тернопіль, Підручники і посібники, 2016. $480 \mathrm{c}$.

Моця, 2007 - Моця О. Київська Русь і країни Європи: характерні риси східнослов'янської державності, рівні міжнародних відносин та напрями контактів // Український історичний журнал. 2007. № 1. С. 4-19. 
Підгаєцький, 2000 - Підгаєцький В. Модернізм і постмодернізм: уявне минуле чи інваріантне майбутнє? // Україна модерна. Ч. 4-5. Львів, 2000. С. 289-316.

Плохій, 2015 - Плохій С. Походження слов'янських націй. Домодерні ідентичності в Україні, Росії та Білорусії. Київ, Критика, 2015. 456 с.

Толочко, 2002 - Толочко А. Воображенная народность // Ruthenica. Вип. 1. Київ, ІІУ НАНУ, 2002. C. $112-117$.

Толочко, 2007 - Толочко П. П. Археология и древняя история (В защиту исторического марксизма). Киев, ИД «Академпериодика», 2007. 104 с.

Яковенко, 2000 - Яковенко Н. Про методологію досліджень середньовічної і ранньомодерної історії України // Наукові праці історичного факультету Запорізького державного університету. Вип. 11. Запоріжжя, 2000. С. 61-73.

Яковенко, 2005 - Яковенко Н. Ранньомодерна українська історія: спірні питання опису й методології // Сучасна українська історіографія: проблеми методології та термінології / під ред. Г. Касьянова. Київ, ІІУ НАНУ, 2005. С. 56-85.

Plokhy, 2006 - Plokhy S. The Origins of the Slavic Nations: Premodern Identities in Russia, Ukraine, and Belarus. Cambridge, Cambridge University Press, 2006. 379 p.

Zaszkilniak, 2016 - Zaszkilniak L. Historiografia ukraińska i postmodernizm: retrospektywy i perspektywy // Klio Polska: studia i materiały z dziejów historiografii Polskiej. T. 8. Warszawa, Instytut Historii PAN, 2016. S. 103-116.

\section{REFERENCES}

Baran, 2005 - Baran V. D., Baran Ya. V. Istorychni vytoky ukrainskoho narodu [Historical origins of the Ukrainian people]. Kyiv, Heneza, 2005. 208 s. [in Ukrainian]

Iakovenko, 2000 - Yakovenko N. Pro metodolohiiu doslidzhen serednovichnoi i rannomodernoi istorii Ukrainy [On the methodology of research of medieval and early-modern history of Ukraine] // Naukovi pratsi istorychnoho fakultetu Zaporizkoho derzhavnoho universytetu. Vyp. 11. Zaporizhzhia, 2000. S. 61-73. [in Ukrainian]

Iakovenko, 2005 - Yakovenko N. Rannomoderna ukrainska istoriia: spirni pytannia opysu y metodolohii [Early-modern Ukrainian History: controversial issues of description and methodology] // Suchasna ukrainska istoriohrafiia: problemy metodolohii ta terminolohii / pid red. H. Kasianova. Kyiv, IIU NANU, 2005. S. 56-85. [in Ukrainian]

Kalakura, 2016 - Kalakura Ya. «Syndrom komunizatsii» istorykiv i yoho zhyvuchist u postradianskii ukrainskii istoriohrafii [«Syndrome of communization» of historians and its persistence in post-soviet Ukrainian historiography] // Istoryk i Vlada: kolektyvna monohrafiia / red. V. Smolii. Kyiv, IIU NANU, 2016. S. 55-76. [in Ukrainian]

Kasianov, 1999 - Kasianov H. V. Teorii natsii ta natsionalizmu [Theories of the nation and nationalism]. Kyiv, Lybid, 1999. 352 s. [in Ukrainian]

Kasianov, 2010 - Kasianov H. V. Danse macabre: holod 1932 - 1933 rokiv u politytsi, masovii svidomosti ta istoriohrafii (1980-ti - pochatok 2000-kh) [Danse macabre: the famine of $1932-1933$ in politics, mass consciousness and historiography (1980s - early 2000s)]. Kyiv, Nash chas, 2010. 271 s. [in Ukrainian]

Kolesnyk, 2001 - Kolesnyk I. Metodolohiia istorii chy istoriia metodolohii: metafory istoriohrafichnoho dyskursu [Methodology of history or history of methodology: metaphors of historiographic discourse] // Ukrainskyi humanitarnyi ohliad. Vyp. 5. Kyiv, 2001. - S. 55-85. [in Ukrainian]

Kotliar, 1995 - Kotliar M. F. Rus yazychnytska: bilia vytokiv skhidnoslovianskoi tsyvilizatsii [Old Rus' is pagan: near the origins of East-Slavic civilization]. Kyiv, Zapovit, 1995. 288 s. [in Ukrainian]

Kulyk, 2012 - Kulyk V. Natsionalistychne proty radianskoho: istorychna pamiat u nezalezhnii Ukraini (2012) [Nationalistic versus Soviet: historical memory in independent Ukraine]. URL: http://www.historians.in.ua. [in Ukrainian]

Kutsyi, 2016 - Kutsyi I. P. Tsyvilizatsiini identychnosti v ukrainskii istoriohrafii kintsia XVIII - pochatku XX st.: mizh Slovianshchynoiu ta Yevropoiu [Civilizational identities in Ukrainian 
historiography of the late XVIII - early XX centuries: between Slavic and Europe]. Ternopil, Pidruchnyky i posibnyky, 2016. 480 s. [in Ukrainian]

Motsia, 2007 - Motsia O. Kyivska Rus i krainy Yevropy: kharakterni rysy skhidnoslovianskoi derzhavnosti, rivni mizhnarodnykh vidnosyn ta napriamy kontaktiv [Kyivan Rus' and the countries of Europe: the characteristics of East-Slavic statehood, the level of international relations and the directions of contacts] // Ukrainskyi istorychnyi zhurnal. 2007. № 1. S. 4-19. [in Ukrainian]

Pidhaietskyi, 2000 - Pidhaietskyi V. Modernizm i postmodernizm: uiavne mynule chy invariantne maibutnie? [Modernism and postmodernism: imaginary past or invariant future?] // Ukraina moderna. Ch. 4-5. Lviv, 2000. S. 289-316. [in Ukrainian]

Plokhy, 2015 - Plokhii S. Pokhodzhennia slovianskykh natsiy. Domoderni identychnosti v Ukraini, Rosii ta Bilorusii [The Origins of the Slavic Nations: Premodern Identities in Ukraine, Russia and Belarus]. Kyiv, Krytyka, 2015. 456 s. [in Ukrainian]

Plokhy, 2006 - Plokhy S. The Origins of the Slavic Nations: Premodern Identities in Russia, Ukraine, and Belarus. Cambridge, Cambridge University Press, 2006. 379 p.

Tolochko, 2002 - Tolochko A. Voobrazhennaia narodnost [Imagined nationality] // Ruthenica. Vyp. 1. Kyiv, IIU NANU, 2002. S. 112-117. [in Russian]

Tolochko, 2007 - Tolochko P. P. Arkheolohyia y drevniaia ystoryia (V zashchytu ystorycheskoho marksyzma) [Archeology and ancient history (In defense of historical Marxism)]. Kyiv, ID «Akademperiodyka», 2007. 104 s. [in Russian]

Videiko, 2015 - Videiko M. Yu. Etnosotsialni transformatsii u Tsentralnii ta Pivdenno-Skhidnii Yevropi V-IV tys. do n. e. [Ethno-social transformations in Central and Southeast Europe V-IV mill. BC]: dys. ... d-ra ist. nauk; 07.00.05 / Kyivskyi natsionalnyi universytet im. T. Shevchenka. Kyiv, 2015. 462 s. [in Ukrainian]

Zashkilniak, 1996 -Zashkilniak L. O. Vstup do metodolohii istorii [Introduction to the methodology of history]. Lviv, LONMIO, 1996. $96 \mathrm{~s}$. [in Ukrainian]

Zashkilniak, 1999 - Zashkilniak L. O. Metodolohiia istorii vid davnyny do suchasnosti [Methodology of history from antiquity to the modern]. Lviv, Lvivskyi derzhavnyi universytet, 1999. 226 s. [in Ukrainian]

Zashkilniak, 2015 - Zashkilniak L. Radianski istorychni mify v suchasnii ukrainskii istoriohrafii: «stare vyno v novykh mikhakh» [Soviet historical myths in modern Ukrainian historiography: «old wine in new barrels»] // Svitlo y tini ukrainskoho radianskoho istoriopysannia / za red. V. Smoliia. Kyiv, IIU NANU, 2015. S. 17-30. [in Ukrainian]

Zaszkilniak, 2016a - Zaszkilniak L. Historiografia ukraińska i postmodernizm: retrospektywy i perspektywy // Klio Polska: studia i materiały z dziejów historiografii Polskiej. T. 8. Warszawa, Instytut Historii PAN, 2016. S. 103-116.

Zashkilniak, 2016b - Zashkilniak L. Pro svobodu i obmezhennia v piznanni mynuloho: ukrainska istoriohrafiia na pochatku XXI stolittia [On freedom and limitations in the knowledge of the past: Ukrainian historiography at the beginning of the XXI century] // Kharkivskyi istoriohrafichnyi zbirnyk. Vyp. 15. Kharkiv, KhNU, 2016. S. 14-27. [in Ukrainian]

Стаття надійшла до редакиії 3.11.2018 p. Стаття рекомендована до друку 14.12.2018 р. 